\title{
The Impact of Biofertilizers and NPK Fertilizers Application on Soil Phosphorus Availability and Yield of Upland Rice in Tropic Dry Land
}

\author{
B.N. Fitriatin ${ }^{1,}, V$. F. Dewi ${ }^{2}$ and $A$. Yuniarti ${ }^{1)}$ \\ ${ }^{1}$ Department of Soil Sciences and Land Resouces Management, Agriculture Faculty, \\ Universitas Padjadjaran - Jatinangor 45363-West Java - Indonesia \\ 2 Agrotechnology, Agriculture Faculty, Universitas Padjadjaran-Jatinangor 45363-West \\ Java - Indonesia
}

\begin{abstract}
Dry land in Indonesia is dominated by marginal soil which have low macro nutrient content, low organic matter content and low soil microbial activity. Improving soil quality it is necessary to increase nutrients availability such as biofertilizers application. Biofertilizers contains beneficial microbial inoculants to increase soil nutrient availability. The use of biofertilizers combined with NPK fertilizer will increase macro nutrients availability and optimize plant growth, thus will increase fertilizers efficiency. This experiment was carried out to study the impact of biofertilizers on available-P, plant P-uptake and yield of upland rice at Land Research of Agriculture Faculty, Universitas Padjadjaran. This experiment used a randomized block design consisting of ten treatments and three replications The treatments consisted with two doses of biofertilizers $\left(50 \mathrm{~kg} \mathrm{ha}^{-1}\right.$ and $\left.75 \mathrm{~kg} \mathrm{ha}^{-1}\right)$ and three doses of $\mathrm{N}, \mathrm{P}, \mathrm{K}$ fertilizers $(100 \%, 75 \%$, and $50 \%$ from recommended doses). Biofertilizers contains $\mathrm{N}$-fixing bacteria and phosphate solubilizing microbes. The result of experiment showed that application of biofertilizers $75 \mathrm{~kg} \mathrm{ha}^{-1}$ and biofertilizers $50 \mathrm{~kg} \mathrm{ha}^{-1}+\mathrm{N}, \mathrm{P}, \mathrm{K} 50 \%$ increased soil phosphorus availability. The application of biofertilizers increased P-uptake up to $81 \%$. Futhermore, biofertilizers $75 \mathrm{~kg} \mathrm{ha}^{-1}+\mathrm{N}, \mathrm{P}, \mathrm{K} 75 \%$ increased the yield of upland rice by $164 \%$.
\end{abstract}

\section{Introduction}

The problem of nutrient phosphorus is the high soil phosphorus content but it is not available for plants. There are several obstacles that make $\mathrm{P}$ in the soil unavailable to plants, especially on acid soils such as Inceptisols. This soil has physical, chemical and biological characteristics that do not support plant growth. Efforts to increase soil productivity can be done by utilizing beneficial soil microbes known as biofertilizers.

Biofertilizers are materials that contain beneficial microbes to increase the availability of soil nutrients and promote plant growth which is a prospect for sustainable agricultural

* Corresponding Author: betty.natalie@unpad.ac.id 
development [1]. The microorganisms that are used as biofertilizers are $\mathrm{N}$-fixing bacteria, $\mathrm{P}$ solubilizing microorganisms, mycorrhizae, and PGPR [2]. It has been widely researched the role of biofertilizers to increase soil nutrient content and crop production. The advantages of biofertilizers, such as reducing the use of chemical fertilizers and environmental pollution, increase nutrient availability and plant growth as well as improving the physical, chemical and biological properties of the soil [3].

One of the microbes that are used as biofertilizers is Azotobacter chroococcum as Nfixing bacteria and also supports plant growth through the synthesis of plant growth supporting substances or commonly called Plant Growth Promoting Rhizobacteria (PGPR) [4]. The other of N-fixing bacteria is Azospirillum) [5]. One of the microbes that are often used in biofertilizers besides $\mathrm{N}$-fixing bacteria is the phosphate solubilizing microbes (PSM). The efficiency of P in the soil can be increased by the use of PSM which is able to solubilizing phosphate that no available into available and can be absorbed by plants [6]. The increase in productivity that occurs is due to biological activity in the soil, where PSM releases phosphatase enzymes and organic acids that cause $\mathrm{P}$ to become available to plants $[7,8]$. The application of PSM increased the soil phosphorus availability [9].

The use of biofertilizers in rice cultivation is expected to increase the availability of $P$ in order to achieve the P needs of the plant so that it can optimize the growth and productivity of upland rice plants and reduce chemical residues caused by inorganic fertilization, especially in acid soils. Therefore, research is needed to study biofertilizers with $\mathrm{N}, \mathrm{P}, \mathrm{K}$ fertilizer applications to determine which one gives the best results in increasing $\mathrm{P}$ content in soil and plants, increasing rice yields and reducing the use of chemical fertilizers.

\section{Material and Method}

The experiment was carried out at the Experimental Field at the Faculty of Agriculture, Universitas Padjadjaran using Inceptisols. The materials used by consortium biofertilizer between N-fixing bacteria were Azotobacter sp., Azospirillum sp. with phosphate solubilizing microbes (Pseudomonas mallei, Burkolderia sp., Aspergillus sp. and Penicillium sp.) were superior isolates selected. N, P, K fertilizer used Urea, Super phosphate and potassium chloride. Upland rice seeds with Luhur 2 variety were obtained from the Indonesian Center for Rice Research.

\subsection{Biofertilizer Preparation}

Biofertilizer was made by culturing each bacteria on Nutrient Broth (NB) media and each fungi on Potato Dextrose Broth (PDB). After being grown on the media (48 hours), the population was calculated and put as much as $15 \%(37.5 \mathrm{ml} / 250 \mathrm{~g}$ carrier $)$ into the carrier material for the mixture of peat and compost with a ratio of $1: 1$.

After incubating for one week, the population of microbes in biofertilizers were calculated. Based on population calculations, the density of each microbe were Aspergillus sp. $3.4 \times 10^{5} \mathrm{CFU} \mathrm{g}^{-1}$, Penicillium $1.4 \times 10^{5} \mathrm{CFU} \mathrm{g}^{-1}$, Pseudomonas mallei $9.6 \times 10^{7} \mathrm{CFU} \mathrm{g}^{-}$ 1, Pseudomonas cepaceae $1.2 \times 10^{8} \mathrm{CFU} \mathrm{g}^{-1}$, Azotobacter sp. $6,4 \times 10^{6} \mathrm{CFU} \mathrm{g}^{-1}$, and Azospirillum sp. $1 \times 10^{7} \mathrm{CFU} \mathrm{g}^{-1}$.

\subsection{Treatment and data analysis}

The experiment used a randomized block design consisting of ten treatments and three replications. The treatments consisted with two doses of biofertilizers $\left(50 \mathrm{~kg} \mathrm{ha}^{-1}\right.$ dan $75 \mathrm{~kg}$ ha- $\left.^{1}\right)$ and three doses of NPK fertilizers (100\%, 75\%, and 50\% from recommended doses). 
The recommended dosage of NPK fertilizers were $300 \mathrm{~kg} \mathrm{ha}^{-1}$ Urea, $100 \mathrm{~kg} \mathrm{ha}^{-1} \mathrm{SP}-36$ (super phosphate) and $100 \mathrm{~kg} \mathrm{ha}^{-1} \mathrm{KCl}$. Soil phosphorus availability was measured by Bray extract and $\mathrm{P}$ content of plant was analyzed by Kjedahl method at the end of vegetative period. Yield of upland rice was measured at the end of generative period. Data were collected to analysis of variance (ANOVA) and treatment means were compared using Duncan test at $\mathrm{p}=0.05$.

\section{Results and Discusscion}

\subsection{Soil Characteristics}

The Inceptisol soil used in this experiment had a $\mathrm{pH}$ of 5.58 (slightly acidic). Upland rice can grow optimally at soil $\mathrm{pH}$ between 5.5 to 8.0 . Soil $\mathrm{pH}$ less than 5.5 or more than 8.0 will cause deficiency of $\mathrm{P}$ elements and too much $\mathrm{Fe}$ and $\mathrm{Al}$ elements will poison to the plants.

This soil contains C-Organic of $1.89 \%$ which includes low criteria, low Total N (0.19\%), low C / N ratio (10), high potential P (44.35mg $\left.100 \mathrm{~g}^{-1}\right)$, but moderate soil P-

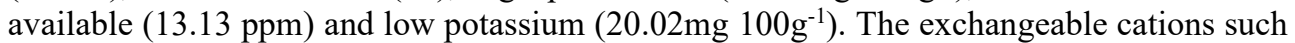
as Ca-dd $6.69 \mathrm{cmol} \mathrm{kg}^{-1}$ were included in the moderate category, low of $\mathrm{Mg}$-dd $(0.93 \mathrm{cmol}$ $\left.\mathrm{kg}^{-1}\right)$, low of K-dd $\left(0.20 \mathrm{cmol} \mathrm{kg}^{-1}\right)$, moderate of Na-dd $\left(0.67 \mathrm{cmol} \mathrm{kg}^{-1}\right)$ and a CEC of $14.98 \mathrm{cmol} \mathrm{kg}^{-1}$ including the low category.

Based on the data from the analysis of the Inceptisol soil used for the study, the soil fertility level is quite low. This can be seen from the low $\mathrm{N}, \mathrm{P}$ and $\mathrm{K}$ content in the soil and low soil organic carbon.

\subsection{Soil phosphorus availability and P-uptakes}

The results of statistical analysis showed that the combination of biofertilizers and N, P, K significantly affected the soil $\mathrm{P}$ availability. Table 1 showed that application of biofertilizers $75 \mathrm{~kg} \mathrm{ha}^{-1}$ and biofertilizers $50 \mathrm{~kg} \mathrm{ha}^{-1}+\mathrm{N}, \mathrm{P}, \mathrm{K} 50 \%$ increased soil phosphorus availability signicantly. The increase in the availability of $\mathrm{P}$ in the soil is the result of the addition of biofertilizers containing P-solubilizing microbes to produce organic acids which increase the availability of $P$ [10]. The phosphate solubilizing microbes as potential biofertilizers and environment-friendly phosphorus biofertilizers to enhance fertilizers efficiency [11].

Table 1. Effect of biofertilizers and N, P, K on P available and P-uptake

\begin{tabular}{|c|c|c|}
\hline Treatments & $\begin{array}{l}\text { Available-P } \\
\text { (ppm) }\end{array}$ & $\begin{array}{l}\text { P-uptake } \\
\text { (mg/plant) }\end{array}$ \\
\hline control & $29.9 \pm 1.25 \mathrm{a}$ & $62.7 \pm 0.53 \mathrm{a}$ \\
\hline $\mathrm{N}, \mathrm{P}, \mathrm{K} 100 \%$ & $31.1 \pm 0.76 \mathrm{ab}$ & $100.6 \pm 1.52 \mathrm{ab}$ \\
\hline $\mathrm{N}, \mathrm{P}, \mathrm{K} 75 \%$ & $31.6 \pm 1.28 \mathrm{~b}$ & $70.4 \pm 0.70 \mathrm{ab}$ \\
\hline $\mathrm{N}, \mathrm{P}, \mathrm{K} 50 \%$ & $30.4 \pm 0.09 \mathrm{ab}$ & $52.1 \pm 2.60 \mathrm{a}$ \\
\hline Biofertilizers $75 \mathrm{~kg} \mathrm{ha-}^{1}$ & $31.8 \pm 1.69 \mathrm{~b}$ & $60.1 \pm 1.94 \mathrm{a}$ \\
\hline Biofertilizers 50 kg ha- ${ }^{1}$ & $30.7 \pm 0.23 \mathrm{ab}$ & $88.5 \pm 1.90 \mathrm{ab}$ \\
\hline Biofertilizers $75 \mathrm{~kg} \mathrm{ha-}^{1}+\mathrm{N}, \mathrm{P}, \mathrm{K} 75 \%$ & $30,5 \pm 0.41 \mathrm{ab}$ & $46.2 \pm 1.23 \mathrm{a}$ \\
\hline Biofertilizers $50 \mathrm{~kg} \mathrm{ha}^{1}+\mathrm{N}, \mathrm{P}, \mathrm{K} 75 \%$ & $31.2 \pm 0.80 \mathrm{ab}$ & $81.5 \pm 0.95 \mathrm{ab}$ \\
\hline Biofertilizers $75 \mathrm{~kg} \mathrm{ha}^{-1}+\mathrm{N}, \mathrm{P}, \mathrm{K} 50 \%$ & $30.8 \pm 0.86 \mathrm{ab}$ & $113.5 \pm 0.90 \mathrm{~b}$ \\
\hline Biofertilizers $50 \mathrm{~kg} \mathrm{ha}^{1}+\mathrm{N}, \mathrm{P}, \mathrm{K} 50 \%$ & $31.8 \pm 0.86 \mathrm{~b}$ & $72.8 \pm 0.69 \mathrm{ab}$ \\
\hline
\end{tabular}

Remarks: The average score followed by the same letter is not significantly different according to the Duncan Test at the $5 \%$ level 
The results of statistical analysis showed that the combination of biofertilizers $75 \mathrm{~kg}$ ha$1+\mathrm{N}, \mathrm{P}, \mathrm{K} 50 \%$ increased P-uptake significantly. Based on the data presented in Table 1 , the P-uptake treated with biofertilizers $75 \mathrm{~kg} \mathrm{ha}^{-1}+\mathrm{N}, \mathrm{P}, \mathrm{K} 50 \%$ was $113.5 \mathrm{mg} / \mathrm{plant}$ while the control treatment was $62.7 \mathrm{mg} /$ plant. This difference indicated that the application of biofertilizers increased the P-uptake up to $81 \%$. These results indicated that biofertilizers containing $\mathrm{P}$-solubilizing microbes and $\mathrm{N}$-fixing bacteria were able to increase the $\mathrm{P}$ content of plants. This is in line with [12] that application of biofertilizer containing Nfixer. P-solubilizer with green manure $C$. juncea increased N, P, and K uptakes and growth of sugarcane.

There are several treatments with $\mathrm{P}$ uptake in plants that are lower than the control treatment, this can be caused by dry land conditions so that the plants lack water, rainfall during planting is very low. Lack of water in these plants will inhibit mass flow in the soil and plant roots. The obstruction of this mass flow will disrupt the absorption of nutrients which can have a direct effect on root development, from soil to plants. According to [13] the absorption of $\mathrm{P}$ nutrients is influenced by the ability of plant roots and plants as a whole, because in some plants the root hair of plants plays an active role in the absorption of $\mathrm{P}$.

\subsection{Yield of upland rice}

The results of experimental showed that the combination of biofertilizer treatment and $\mathrm{N}, \mathrm{P}$, $\mathrm{K}$ fertilizers significantly affected upland rice yield (dry grain weight). Table 2 showed that the best treatment to increase the yield was the treatment of biofertilizer $75 \mathrm{~kg} \mathrm{ha}^{-1}+\mathrm{N}, \mathrm{P}$, $\mathrm{K} 75 \%$, with yield of upland rice $406.77 \mathrm{~g}$, whereas in the control only $153.99 \mathrm{~g}$. The difference between these treatments indicated that the application of biofertilizers was able to increase the yield of upland rice by $164 \%$. The increasing iof upland rice yields was due to the availability of nutrients facilitated by P-solubilizing microbes. The application of phosphate solubilizing microbes combined with bio-organic phosphate increased soil $\mathrm{P}$ content and crop production [14].

Table 2. Effect of biofertilizers and N, P, K on yield of upland rice

\begin{tabular}{|c|c|c|}
\hline Treatments & Yield (g) & Weights 1000 grains \\
\hline control & $153.99 \pm 8.97 \mathrm{a}$ & $17.53 \pm 0.53 \mathrm{a}$ \\
\hline $\mathrm{N}, \mathrm{P}, \mathrm{K} 100 \%$ & $189.82 \pm 8.34 \mathrm{a}$ & $19.13 \pm 1.52 \mathrm{a}$ \\
\hline $\mathrm{N}, \mathrm{P}, \mathrm{K} 75 \%$ & $171.95 \pm 6.81 \mathrm{a}$ & $19.30 \pm 0.70 \mathrm{a}$ \\
\hline $\mathrm{N}, \mathrm{P}, \mathrm{K} 50 \%$ & $163.66 \pm 6.86 \mathrm{a}$ & $21.73 \pm 5.60 \mathrm{a}$ \\
\hline Biofertilizers $75 \mathrm{~kg} \mathrm{ha-}{ }^{1}$ & $223.2 \pm 8.68 \mathrm{ab}$ & $19.03 \pm 1.94 \mathrm{a}$ \\
\hline Biofertilizers 50 kg ha- ${ }^{1}$ & $161.54 \pm 9.93 \mathrm{a}$ & $18.90 \pm 1.90 \mathrm{a}$ \\
\hline Biofertilizers $75 \mathrm{~kg} \mathrm{ha}^{1}+\mathrm{N}, \mathrm{P}, \mathrm{K} 75 \%$ & $406.77 \pm 8.13 b$ & $19.63 \pm 1.23 \mathrm{a}$ \\
\hline Biofertilizers $50 \mathrm{~kg} \mathrm{ha}^{1}+\mathrm{N}, \mathrm{P}, \mathrm{K} 75 \%$ & $269.98 \pm 7.57 \mathrm{ab}$ & $19.83 \pm 0.95 \mathrm{a}$ \\
\hline Biofertilizers $75 \mathrm{~kg} \mathrm{ha}^{1}+\mathrm{N}, \mathrm{P}, \mathrm{K} 50 \%$ & $319.98 \pm 9.66 \mathrm{ab}$ & $19.47 \pm 0.90 \mathrm{a}$ \\
\hline Biofertilizers $50 \mathrm{~kg}$ ha- $^{1}+\mathrm{N}, \mathrm{P}, \mathrm{K} 50 \%$ & $186.84 \pm 6.90 \mathrm{a}$ & $19.20 \pm 0.69 \mathrm{a}$ \\
\hline
\end{tabular}

Remarks: The average score followed by the same letter is not significantly different according to the Duncan Test at the 5\% level 
Based on the results of statistical analysis, the combination of biofertilizer and N, P, K fertilizers did not significantly affect the weight of 1000 grains. The weight of 1000 grains in upland rice $\mathrm{p}$ treated with $\mathrm{N}, \mathrm{P}, \mathrm{K} 50 \%$ fertilizer was $21.73 \mathrm{~g}$, this weight greater than the treatment of biofertilizers and $\mathrm{N}, \mathrm{P}, \mathrm{K}$. The weight of 1000 grains from the treated by biofertilizer $50 \mathrm{~kg} \mathrm{ha}^{-1}+\mathrm{N}, \mathrm{P}, \mathrm{K} 75 \%$ was $19.83 \mathrm{~g}$, in case compared with the control treatment which produced a 1000 grain weight of $17.53 \mathrm{~g}$, the treatment of biological fertilizers and N, P, K was still better. This difference indicates that the application of biological fertilizers to upland rice plants increases the weight of 1000 grains in plants by up to $13 \%$, although this treatment did not affect significantly.

The weight of 1000 grains is influenced by several factors, both internal and external factors. Internal factors are the genetical conditions of the plant, while external factors include drought stress or water availability [15]. In this experiment, water availability was not very good because the rainfall on the experimental land was very low. Genetically, upland rice varieties Luhur 2 generally produce a weight of 1000 grains $24.6 \mathrm{~g}$.

\section{Conclusions}

The application of biofertilizers containing $\mathrm{P}$ solubilizing microbes and $\mathrm{N}$-fixing bacteria as well as N, P, K fertilizers increased available P, P uptake and yield of upland rice. The result of experiment showed that application of biofertilizers $75 \mathrm{~kg} \mathrm{ha}^{-1}$ and biofertilizers 50 $\mathrm{kg} \mathrm{ha} \mathrm{h}^{-1}+\mathrm{N}, \mathrm{P}, \mathrm{K} 50 \%$ increased soil phosphorus availability. The application of biofertilizers $75 \mathrm{~kg} \mathrm{ha}^{-1}+\mathrm{N}, \mathrm{P}, \mathrm{K} 75 \%$ increased the yield of upland rice by $164 \%$. Biofertilizers application increased fertilizers efficiency up to $25 \%$ in dry land.

Acknowledgments. Part of this work was carried out within the financial support from the Directorate General of Higher Education Ministry of Research and Technology Indonesia. The authors would like to thank staff Laboratory of Soil Biology Faculty of Agriculture, Universitas Padjadjaran for their cooperation.

\section{References}

1 M. Mącik, A, Gryta and M. Frąc. Advances of Agronomy.Vol. 162: 31-87 (2020).

2 P. Chaudhary, D. Jain, K. Anand, and D. Mitra. Biofertilizer: A sustainable approach for plant and soil health In book: Microbial Resources for Sustainable Agriculture. Publisher: LAP LAMBERT Academic Publishin. https://www.researchgate.net/publication/336554622 (2019)

3 MR. Wahane, NA. Meshram, SS. More and NH. Khobragade. The Pharma Innovation Journal. 9(7): 127-130 (2020)

4 SA. Wani, S. Chand, dan T. Ali. Potential use of Azotobacter chroococcum in crop production: an overview. Current Agriculture Research Journal Vol. 1(1): 35-38. Shere-Kashmir University of Agricultural Sciences and Technology-Shalimar, Kashmir, India. (2013)

5 F. Constantinescu, and Sorina. Azospirillum strains as biofertilizers and biocontrol agents. Journal of Advances in Agriculture. 7: https://www.researchgate.net/publication/ 323906256 (2017).

6 G.Kalayu. Phosphate solubilizing microorganisms: Promising approach as biofertilizers. International Journal of Agronomy. Article ID 4917256:https://doi.org/10.1155/2019/4917256 (2019). 
7 B. Alaylar, D. Egamberdieva, M. Gulluce., M. Karadayi., and N.K. Arora. Integration of molecular tools in microbial phosphate solubilization research in agriculture perspective. World Journal of Microbiology and Biotechnology 36:93 https://doi.org/10.1007/s11274-020-02870 (2020)

8 BN. Fitriatin, D. Fauziah, F.N. Fitriani, D.N. Ningtyas, P.Suryatmana, R.Hindersah, M.R. Setiawati, T. Simarmata. Biochemical activity and bioassay on maize seedling of selected indigenous phosphate-solubilizing bacteria isolated from the acid soil ecosystem. Open Agriculture 5: 300-304 (2020)

9 V. Prasad, S. Chaudhary., and A. Singh. Improving phosphorus fertility in soil through microbial mediators. International Journal of Plant and Environment Vol. 4, No. 2. 1-8 (2018)

10 GX. Li, X.Q. Wu., J.R. Ye., and H.C. Yang. Characteristics of organic acid secretion associated with the interaction between Burkholderia multivorans WS-FJ9 and poplar root system. BioMed Research International Volume 2018, Article ID 9619724: 1-12 https://doi.org/10.1155/2018/9619724 (2018)

11 SB. Sharma, R. Z Sayyed, M.H Trivedi and T. A Gobi. Phosphate solubilizing microbes: sustainable approach for managing phosphorus deficiency in agricultural soils. SpringerPlus, 2:587. http://www.springerplus.com/content/2/1/58 (2013)

12 Djajadi, R. Syaputra., and S.N. Hidayati. Effect of NPK fertilizer, biofertilizer containing $\mathrm{N}$ fixer and $\mathrm{P}$ solubilizer, and green manure of $C$. juncea on nutrients uptake and growth of sugarcane. 1st International Conference on Sustainable Plantation (1st ICSP 2019). IOP Conf. Series: Earth and Environmental Science 418 (2020) 012068 IOP Publishing doi:10.1088/1755-1315/418/1/012068 (2020)

13 S. Ruiz, N. Koebernick., S. Duncan., D.M. Fletcher., C. Scotson., A. Boghi., M. Marin., A.G. Bengough., T.S. George., L.K. Brown., P.D. Hallett., and T. Roose. Significance of root hairs at the field scale - modelling root water and phosphorus uptake under different field conditions. Plant Soil 447:281-304. https://doi.org/10.1007/s11104-019-04308-2 (2020)

14 M. Tahir, U. Khalide, M. Ijaz b, G.M. Shaha, M.A. Naeema, M. Shahidd, K. Mahmoode, N. Ahmada, F. Kareem. Combined application of bio-organic phosphate and phosphorus solubilizing bacteria (Bacillus strain MWT 14) improve the performance of bread wheat with low fertilizer input under an arid climate. Brazilian Journal of Microbiology. 49 : 15-24. (2018)

15 A. Raza, A. Razzaq, S.S.Mehmood, X. Zou, X. Zhang 1,Yan Lv and J.Xu. Impact of Climate Change on Crops Adaptation and Strategies to Tackle Its Outcome: A Review. Plants, 8, 34; doi:10.3390/plants8020034 (2019) 